Pesq. Vet. Bras. 36(11):1087-1090, novembro 2016 DOI: 10.1590/S0100-736X2016001100005

\title{
Resistance to rupture of the equine stomach ${ }^{1}$
}

\author{
Paula A. Di Filippo ${ }^{2 *}$, Ítalo S. Coutinho², Marcos A.D. Meireles ${ }^{2}$ and Ana B.F. Rodrigues ${ }^{3}$
}

\begin{abstract}
Di Filippo P.A., Coutinho I.S., Meireles M.A.D. \& Rodrigues A.B.F. 2016. Resistance to rupture of the equine stomach. Pesquisa Veterinária Brasileira 36(11):10871090. Laboratório de Clínicas e Cirurgia Veterinária, Centro de Ciências e Tecnologias Agropecuárias, Universidade Estadual do Norte Fluminense Darcy Ribeiro, Av. Alberto Lamego 2000, Campos dos Goytacazes, RJ 28013-602, Brazil. E-mail: pdf@uenf.br

Equine colic is an important and common cause of disease and death in horses. Gastric rupture has been extensively described in the literature, and is known to affect expressive numbers of horses. Gastric dilatation, which precedes rupture, may be observed when the animal consumes large amounts of recently harvested grass or drinks water too fast, though diagnosis criteria also include infestation with Gastherophilus and the presence of ileus and distal intestinal obstructions. The objective of the present study was to determine the resistance to rupture of the equine stomach to air ( $\mathrm{mm} \mathrm{Hg}$ ) and water (L) injection. Forty stomachs of young horses (20 geldings and 20 mares) with no defined breed were analyzed. Total organ length $(\mathrm{cm})$, weight $(\mathrm{g})$, greater curved length $(\mathrm{cm})$, lesser curved length $(\mathrm{cm})$ and height $(\mathrm{cm})$ were measured, with no statistical difference between males and females $(p>.05)$. However, stomachs of horses were larger than those of mares and therefore presented higher volumetric capacity $(p<0.05)$. No difference between males and females was observed in the pressure assay ( $93 \mathrm{mmg} \mathrm{Hg}$ ). Rupture occurred along the greater curvature (99\%) and on the visceral (80\%) and diaphragmatic (20\%) surfaces, across all layers of the gastric wall. Although the equine stomach is relatively small, the organ is considerably resistant to rupture, whether by injection of air or liquid. Horses and mares exhibit similar resistance values, although the stomach of females has smaller volumetric capacity.
\end{abstract}

INDEX TERMS: Rupture, stomach, colic, gastric dilatation, gastric resistance, horses.

RESUMO.- [Resistência à ruptura do estômago equino.] A cólica é um dos problemas mais comuns na clínica de equinos sendo responsável por grande número de mortes. A ruptura gástrica tem sido amplamente descrita na literatura e acomete número expressivo de animais. A dilatação gástrica, que antecede a ruptura, pode advir do consumo excessivo de capim recém-cortado, ingestão rápida de água, infestação por Gastherophilus, ocorrência de íleo paralítico e obstruções intestinais distais. A ruptura gástrica tem sido amplamente descrita na literatura e acomete um

\footnotetext{
${ }^{1}$ Received on July 16, 2015.

Accepted for publication on July 23, 2016.

${ }^{2}$ Laboratório de Clínicas e Cirurgia Veterinária, Centro de Ciências e Tecnologias Agropecuárias (CCTA), Universidade Estadual do Norte Fluminense Darcy Ribeiro (UENF), Av. Alberto Lamego 2000, Campos dos Goytacazes, RJ 28013-602, Brazil. E-mails: is.coutinho@hotmail.com, marcosadmeireles@yahoo.com.br; *Corresponding author: pdf@uenf.br

${ }^{3}$ Laboratório de Morfologia e Patologia Animal, CCTA, UENF. E-mail: anaanatomiaanimal@gmail.com
}

número expressivo de animais. Este estudo objetivou determinar a resistência à ruptura do estômago equino mediante a insuflação de ar atmosférico ( $\mathrm{mmHg}$ ) e do preenchimento com água (L). Foram utilizados 40 estômagos de equinos adultos jovens (20 machos castrados e 20 fêmeas) sem raça definida. Medidas relativas ao comprimento total do órgão $(\mathrm{cm})$, peso do órgão $(\mathrm{g})$, curvatura maior $(\mathrm{cm})$, curvatura menor $(\mathrm{cm})$ e altura $(\mathrm{cm})$ foram aferidas e não diferiram entre machos e fêmeas $(p>0,05)$. No entanto, os estômagos dos machos apresentaram medidas superiores as das fêmeas e por assim serem, comportaram um maior volume de água $(\mathrm{p}<0,05)$. No teste de resistência mediante insuflação de ar atmosférico não houve diferença entre machos e fêmeas $(93 \mathrm{mmHg})$. Os rompimentos ocorreram ao longo da curvatura maior (99\%) nas faces visceral (80\%) e diafragmática (20\%) e abrangeram todas as camadas da parede gástrica. Apesar de ser um órgão relativamente pequeno, o estômago dos equinos apresenta considerável resistência à ruptura, seja por líquido ou por ar atmosférico. 
Machos e fêmeas possuem resistência gástrica semelhante, embora o estômago das fêmeas equinas comporte um menor volume.

TERMOS DE INDEXAÇÃO: Ruptura, estomago, cólica, dilatação gástrica, resistência gástrica, equinos.

\section{INTRODUCTION}

Colic is a common disease in horses practice (Tinker et al. 1997) and is an important cause of death in horses (Cohen $\&$ Gibbs 1999). The cause of the equine colic is divided into gastrointestinal and non-gastrointestinal (Abutarbush et al. 2005). The stomach of the horse may undergo phatological changes of its wall associated with gastric ulcer, dilatation, rupture, impaction or neoplasia (Blikslager et al. 2006, Kasap et al. 2010, Tamzali et al. 2011, Vainio et al. 2011).

Gastric dilation is the most common gastrointestinal condition observed in horses, accounting for approximately $62.6 \%$ and $76.5 \%$ of cases of colic in the military units. Gastric dilation, which precedes rupture, may be primary, when it is a consequence of diseases affecting the stomach only, or secondary, when it results from distal obstruction against the flow of ingested contents (Freeman 1982, Hillyer et al. 2001). Rupture may occur even in the absence of significant gastric expansion, due to gastric wall infarction or, more rarely, perforation secondary to ulceration (Robertson 1990, Edwards 2003).

Gastric rupture is potentially fatal to horses, since the contamination of an abdominal cavity with gastric contents induces peritonitis and septic shock within short periods of time (Blikslager et al. 2006). One successful repair of a partial rupture in an adult horse has been described (Steenhaut et al. 1986) however, only the seromuscular layer of the stomach wall was torn, and there was no contamination of the peritoneal cavity with gastric contents (Kiper et al. 1990). Gastric rupture causes severe pain, tachycardia, abdominal distension, and cyanotic mucosae (Kasap et al. 2010). The diagnostic of gastric rupture can be by surgical exploration or necropsy examination. Additionally, gastroscopy may be used as ancillary diagnostic procedure (Todhunter et al. 1986).

Gastric rupture has been extensively described in the literature, and is known to affect expressive numbers of horses (Kiper et al. 1990, Kasap et al. 2010). In a previous review of 54 horses with gastric rupture, the rupture was most often associated with gastrointestinal obstruction, especially small intestinal obstruction (Todhunter et al. 1986). Most ruptures occur along the greater stomach curvature (Robertson 1990), with no predisposition for breed, gender, or age (Todhunter et al. 1986, Kiper et al. 1990). The objective of the present study was to determine the resistance to rupture of the equine stomach using air and water based on morphometric and histological analyses.

\section{MATERIALS AND METHODS}

Forty stomachs of young horses (20 geldings and 20 mares) with no defined breed were analyzed. (Table 1 ). The organs were removed from euthanized animals affected with irreversible pathologies that did not compromise the gastric function. After euthanasia, abdomens were sectioned and stomachs were removed. Contents were flushed using water, and stomachs were mechanically cleaned using saline $0.9 \%$, with special care to preserve structural integrity of the organs. After removal of excess water, measurements were carried out using a caliper, a measuring tape, and portable electronic scales.

Morphology measurements were conducted by the same observer, and included (i) total organ length, as the lengthwise distance between the fundus and the pylorus end; (ii) the greater curvature length, as the distance from the gastric cardia to the pylorus measured along the convex ventral edge of the stomach; (iii) the lesser curvature length, as the distance between the cardia and the pylorus measured along the dorsal concave edge; (iv) height, as the distance between the greater and the lesser curvature measured vertically along the stomach's body (median line); and (v) weight. All length measurements are expressed in centimeters. Weight is expressed in grams.

To evaluate resistance to the injection of air, the pylorus was sown up with surgical cotton thread. Then, a silicon probe was

Table 1. Mean \pm standard deviation and maximum (max) and minimum (min) values of age an body weight of horses

\begin{tabular}{|c|c|c|c|c|c|c|}
\hline \multirow[t]{3}{*}{ Parameters } & \multicolumn{6}{|c|}{ Horses } \\
\hline & \multicolumn{3}{|c|}{ Female } & \multicolumn{3}{|c|}{ Male } \\
\hline & $\mathrm{M} \pm \mathrm{SD}$ & $\max$ & $\min$ & $\mathrm{M} \pm \mathrm{SD}$ & $\max$ & $\min$ \\
\hline $\begin{array}{l}\text { Age of horses } \\
\text { (years) }\end{array}$ & $4.57 \pm 1.83$ & 8 & 2 & $5.19 \pm 1.90$ & 10 & 2.5 \\
\hline $\begin{array}{l}\text { Weight of } \\
\text { horses (kg) }\end{array}$ & $389.48 \pm 47.97$ & 480 & 280 & $403.05 \pm 42.47$ & 480 & 325 \\
\hline
\end{tabular}

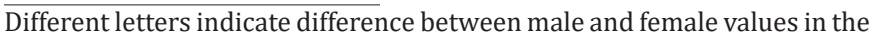
Tukey test $(\mathrm{p}<.05)$.

Table 2. Mean \pm standard deviation and maximum (max) and minimum (min) values of gastric morphology measurements, total stomach volumetric capacity, and rupture pressure of 40 equine stomachs

\begin{tabular}{|c|c|c|c|c|c|c|}
\hline \multirow[t]{3}{*}{ Parameters } & \multicolumn{6}{|c|}{ Horses } \\
\hline & \multicolumn{3}{|c|}{ Female } & \multicolumn{3}{|l|}{ Male } \\
\hline & $\mathrm{M} \pm \mathrm{SD}$ & $\max$ & $\min$ & $\mathrm{M} \pm \mathrm{SD}$ & $\max$ & $\min$ \\
\hline Weight (g) & $971.25 \pm 119.64$ & 1131 & 651 & $932.15 \pm 131.82$ & 1800 & 651 \\
\hline Greater curvature $(\mathrm{cm})$ & $74.05 \pm 7.50$ & 91 & 62 & $76.50 \pm 10.21$ & 106 & 62 \\
\hline Lesser curvature $(\mathrm{cm})$ & $11.45 \pm 2.21$ & 15 & 7 & $12.05 \pm 2.60$ & 18 & 8 \\
\hline Total length $(\mathrm{cm})$ & $29.60 \pm 3.39$ & 36 & 23 & $30.52 \pm 4.19$ & 43 & 24 \\
\hline Height $(\mathrm{cm})$ & $20.27 \pm 2.29$ & 23 & 16 & $20.47 \pm 4.69$ & 32 & 13 \\
\hline Maximum volumetric capacity (L) & $15.81 \pm 4.63^{\mathrm{b}}$ & 22.5 & 7.5 & $18.02 \pm 4.58 \mathrm{a}$ & 26 & 11 \\
\hline Rupture pressure (mmHg) & $93.01 \pm 10.87$ & 110 & 82 & $93.30 \pm 8.92$ & 110 & 82 \\
\hline
\end{tabular}

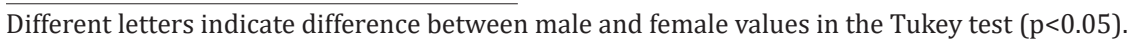


inserted in the esophageal section and fixed using surgical cotton thread. An aneroid manometer was connected to the probe, and stomachs were immersed in water and injected with air at $0.1 \mathrm{~mL} / \mathrm{s}$. The release of bubbles in the water from a rupture indicated the occurrence of rupture, when pressure was measured in mm Hg (Santos et al. 2012).

The maximum volumetric capacity of stomachs was measured using cotton threads as a means to block the passage caudally to the pylorus. Using a silicon probe, stomachs were filled with water upon rupture, when the injection was promptly stopped and the volume of water was measured in a graduated glass measuring cylinder (Nussio et al. 2003).

Each test was conducted using 20 stomachs, 10 of horses and 10 of mares, totaling 40 organs. After the tests, stomachs were sectioned for gross inspection. Upon detection of erosive lesions that may lower the resistance the gastric tissue, fragments of tissues of different areas of the organ were excised and fixed in formalin $10 \%$. Subsequently, specimens were submitted to conventional histopathology investigation. Only healthy organs were considered in the analysis of capacity and resistance results.

The results obtained were submitted to an analysis of variance (ANOVA) and means were compared using the Tukey test with significance level at $\mathrm{p}<0.05$.

\section{RESULTS}

Table 1 lists the minimum and maximum values of age (years) and body weight ( $\mathrm{kg}$ ) of animals. No difference was observed $(p>0.05)$ between males and females.

Table 2 lists the minimum and maximum values of gastric morphometric measurements, maximum stomach volumetric capacity, and rupture pressure of stomachs. No statistically significant difference was observed $(p>0.05)$ in stomach length between males and females. However, stomachs of females were smaller and heavier.

The maximum total volumetric capacity of horses was larger than that of mares $(\mathrm{p}<0.05)$. Mean water volume required for stomachs to burst was $19.02 \mathrm{~L}$ (4.71\% of body weight) and $15.81 \mathrm{~L}$ ( $4.06 \%$ of body weight) for horses and mares respectively.

No statistically significance was observed in the values of rupture pressure upon injection of air between horses and mares $(p>0.05)$. Mean resistance of stomachs was $93 \mathrm{mmHg}$.

\section{DISCUSSION}

In the equine stomach, most of the digesta are held for a limited period of time (2-6 h). When fresh digesta are offered, the stomach initiates soft peristaltic contractions and most of the old digesta are leaving to the duodenum (Gerring \& Hunt 1986). As soon as feed intake has stopped, these contractions will be decreased and the passage of feed into the duodenum will stop. Nevertheless, the stomach is rarely completely empty (Van Weyenberg et al. 2006). In this sense, and considering that in cases of equine colic it is common the accumulation of fluids in the stomach of these animals and that horses with dehydration are often treated with hydro-electrolytic replacement using nasogastric tubes (Hillyer et al. 2001), the difference in maximum volumetric capacity between males and females $(18.02 \mathrm{~L}$ and $15.81 \mathrm{~L}$ respectively) points to the need to proceed cautiou- sly during enteral fluid replacement to prevent gastric dilation and possible rupture in mares.

Furthermore, study by Todhunter et al. (1986) demonstrated that the mere presence of an indwelling nasogastric tube did not prevent gastric rupture. In this study six horses had gastric rupture in the postoperative period and the rupture could be attributed to secondary gastric dilatation which resulted from ileus. The horses had nasogastric tubes in place at the time of gastric rupture. Therefore, in horses in which there is a high index of suspicion of gastric dilation, every effort should be made to decompress the stomach promptly and repeatedly (Todhunter et al. 1986). Moreover, a distended stomach stimulates an inhibitory reflex to the duodenum which could depress jejunal function (Van Weyenberg et al. 2006). Exacerbating gastric dilation and increasing the chances of rupture.

The results of a study that analyzed the stomachs of 40 English thoroughbred horses (20 males and 20 females) clarified the existence of significant differences between gastric volumetric capacities of horses (12.27 L) and mares (9.56 L) (Fernandes Filho 1975). In that study, the volumes published corresponded to the maximum capacity when the pressure inside the stomach equaled the environmental pressure, prior to rupture upon maximum distension.

The rupture test based on the injection of air showed horses and mares have similar values of stomach rupture pressure $(93 \mathrm{~mm} \mathrm{Hg})$. The method used in the present study has been described by other authors (Baldez et al. 2006, Nomura et al. 2009), for whom the technique affords the most reliable results when the aim is to measure resistance of hollow organs, since it simulates the intraluminal hypertension as observed in clinical practice during the rupture of viscera. In other words, the test faithfully represents the pressure vectors acting on the gastric wall during distension (Batista et al. 2006, Santos et al. 2012). Another advantage is that the methodology allows pressure to develop evenly across the gastric wall, which is not observed in conventional traction tests that do not simulate any factual situation in practice (Nomura et al. 2009). In this sense, a physical mechanism for gastric dilation and rupture in horses has been postulated (Nickel et al. 1979).

In the present study, rupture occurred across all layers of the gastric wall, near the greater curvature (99\%), on the visceral (80\%) and diaphragmatic surfaces (20\%). Ruptures affected both the glandular and the non-glandular portions, and usually measured $20 \mathrm{~cm}$. Histologically, the structural and functional differences between the epithelia of the two mucosae influence the aspect of ulcerative lesions on the gastric wall (Murray 1999, Andrews et al. 2006). However, no study has evaluated and compared the distension of the gastric wall in the glandular and the non-glandular portions. Similar findings were reported for horses presenting gastric rupture due to natural causes, that is, most lesions were observed near the greater curvature and affected both areas of the mucosa (Todhunter et al. 1986, Kiper et al. 1990, Kasap et al. 2010).

In this study the animals had two to seven years age. Younger horses may be less predisposed to gastric ruptu- 
re since their gastric wall is more compliant, except where the gastric wall is weakened by ulceration (Todhunter et al. 1986). Additional studies can be conducted to compare the maximum volumetric capacity and age.

\section{CONCLUSIONS}

The results obtained in the present study suggest that, although the equine stomach is a small organ, compared with the subsequent compartments of these animals' digestive tract, it exhibits considerable resistance to distention by injection of either air or water.

Resistance values were similar for males and females, but the stomach of females was shown to lodge smaller volume of liquids.

\section{REFERENCES}

Abutarbush S.M., Carmalt J.L. \& Shoemaker R.W. 2005. Causes of gastrointestinal colic in horses in western Canada: 604 cases (1992-2002). Can. Vet. J. 46(9):800-805.

Andrews F.M., Buchanan B.R., Smith S.H., Elliott S.B. \& Saxton A.M. 2006. In vitro effects of hydrochloric acid and various concentrations of acetic, propionic, butyric, or valeric acids on bioelectric properties of equine gastric squamous mucosa. Am. J. Vet. Res. 67(11):1873-1882.

Baldez R.N., Malafaia O., Czeczko N.G., Martins N.L.P., Ferreira L.M., Ribas C.A.P.M., Salles Júnior G., Del Claro R.P., Santos L.O.M., Graça Neto L. \& Araújo L.R.R. 2006. Healing of colonic anastomosis with the use of extract aqueous of Orbignya phalerata (Babassu) in rats. Acta Cir. Bras. 21(2):31-38.

Batista C.P., Torres O.J.M., Matias J.E.F., Moreira A.T.R., Colman D., Lima J.H.F., Macri M.M., Rauen Júnior R.J., Ferreira L.M. \& Freitas A.C.T. 2006. Effect of watery extract of Orbignya phalerata (babassu) in the gastric healing in rats: morphologic and tensiometric study. Acta Cir. Bras. 21(3):26-31.

Blikslager A.T. \& Wilson D.A. 2006. Stomach and spleen, p.377. In: Auer J.A. \& Stick J.A. (Eds), Equine Surgery. 3rd ed. W.B. Saunders, St Louis.

Cohen N. \& Gibbs P. 1999. Dietary and other management factors associated with equine colic. J. Am. Vet. Med. Assoc. 45:96-98.

Edwards G.B. 2003. Gastric pathology. 8th Congress on Equine Medicine and Surgery, Geneva, Switzerland.

Fernandes Filho A., Borelli V., D'errico A.A. \& Pereira J.G.L. 1975. The capacity of the stomach in thoroughbred horses. Revta Fac. Med. Vet. Zootec. USP 12:23-26.

Freeman D.E. 1982. The stomach. p.497-516. In: Equine Medicine and Surgery. 3rd ed. Mansmann R.A and McAllister E.S. American Veterinary Publications, Santa Barbara.
Gerring E.L. \& Hunt J.M. 1986. Pathophysiology of equine postoperative ileus: Effect of adrenergic blockade, parasympathetic stimulation and metoclopramide in an experimental model. Equine Vet. J. 18(4):249255.

Hillyer M.H., Taylor F.G. \& French N.P. 2001. A cross-sectional study of colic in horses on Thoroughbred training premises in the British Isles in 1997. Equine Vet. J. 33(4):380-385.

Kasap S., Salci H., Kennerman E., Alasonyalilar A. \& Yilmaz R. 2010. Gastric rupture in a horse. Kafkas Univ. Vet. Fak. Derg. 16(4):707-708.

Kiper M.L., Traub-Dargatz J. \& Curtis C.R. 1999. Gastric rupture in horses: 50 cases (1979-1987). J. Am. Vet. Med. Assoc. 196(2):333-336.

Murray M.J. 1999. Gastroduodenal ulceration in foals. Equine Vet. Educ. 11(4):199-207.

Nickel R., Schummer A. \& Seiferle E. 1979. The alimentary canal of the horse, p.180-198. In: Ibid. (Eds), The Viscera of the Domestic Mammals. 2nd ed. Paul Parey, Berlin.

Nomura L.M., Ribas-Filho J.M., Malafaia O., Dietz U.A., Skare T.L. \& Kume M.H. 2009. Healing process with polypropylene, polyglecaprone 25 and glycomer 60 in cecorraphy in rats. Arq. Bras. Cir. Dig. 22(2):82-88.

Nussio C.M.B., Santos F.A.P., Zopollatto M., Pires A.V., Morais J.B. \& Fernandes J.J.R. 2003. Ruminal fermentation parameters and metric measurements of the rumen of dairy calves fed processed corn (Steam-rolled vs. Steam-flaked) and monensin. Revt Bras. Zootec. 32(4):1021-1031.

Robertson J.T. 1990. Disease of the stomach, p.345-346. In: White N.A. (Ed.), The Equine Acute Abdomen. 2nd ed. Lea and Febiger, Pennsylvania.

Santos O.J., Barros-Filho A.K.D., Malafaia O., Ribas-Filho J.M., Santos R.H.P. \& Santos R.A.P. 2012. Schinus terebinthifolius raddi (Anacardiaceae) in the healing process of gastrorraphy in rats. Arq. Bras. Cir. Dig. 25(3): 140-146.

Steenhaut M., Vlaminck K. \& Gasthuys F. 1986. Surgical repair of a partial gastric rupture in a horse. Equine Vet. J. 18:331-332.

Tamzali Y., Marguet C., Priymenko N. \& Lyazrhi F. 2011. Prevalence of gastric ulcer syndrome in high-level endurance horses. Equine Vet. J. 43(2):141-144.

Tinker M.K., White N.A., Lessard P., Thatcher C.D., Pelzer K.D., Davis B. \& Carmel D.K. 1997. Prospective study of equine colic incidence and mortality. Equine Vet. J. 29:448-453.

Todhunter R., Hollis N. \& Roth L. 1986. Gastric rupture in horses: a review of 54 cases. Equine Vet. J. 18(4):288-293.

Vainio K., Sykes B.W. \& Blikslager A.T. 2011. Primary gastric impaction in horses: a retrospective study of 20 cases (2005-2008). Equine Vet. Educ. 23(4):186-190.

Van Weyenberg S., Sales J. \& Janssens G.P.J. 2006. Passage rate of digesta through the equine gastrointestinal tract: a review. Livest. Sci. 99:3-12. 